\title{
An efficient purification method for high recovery of Recombinant Human Granulocyte Colony Stimulating Factor from recombinant E. coli
}

\author{
S. Abolghasemi Dehaghani ${ }^{1+}$, V. Babaeipour ${ }^{2+}$, M. R. Mofid ${ }^{3}$, A. Divsalar ${ }^{4}$, F. Faraji ${ }^{1}$
}

\begin{abstract}
Human G-CSF, a single chain polypeptide containing 174 amino acid residues $(M W=18,800, p I=6.1)$, is one of the hemopoietic growth factors. Development of inexpensive and simple culture media is always favorable for commercial production of recombinant proteins in E. coli.

The high-level expression of eukaryotic proteins in E. coli often leads to formation of insoluble inclusion bodies (IBs) in the cytoplasm or periplasm. Recovery of active material from (IBs) is often difficult and involves two general steps: protein solubilization in a denaturant and protein refolding.

On a commercial scale, reducing the number of protein purification steps is practical and economical because each purification step not only increases the final product but also causes successive yield losses of the recombinant protein.

In this research, we developed an efficient and scalable procedure for production and purification of recombinant human (rh-GCSF) of E. coli. This process include: an optimized batch culture with $\mathrm{LB}$ and glucose $10 \mathrm{~g} / \mathrm{l}$ with expression level $40 \%$, cell harvesting, cell lyses with high pressure homogenizer, two steps washing, IB solubilization, refolding, and finally protein purified by FPLC with cation exchanger column. By the using of the new developed method, of $1.8 \mathrm{~g} \mathrm{l-1} \mathrm{rh}-\mathrm{GCSF}$ was produced in each batch, $720 \mathrm{mg}$ pure of recombinant protein was obtained with recovery yield about $40 \%$ and purity over than $99 \%$. According to available data this is one of the highest yield and production level of the purified recombinant protein that has been reported for human recombinant protein which is expressed in E. coli. Also with this procedure we can produce a protein that the structural characterization was preserved.
\end{abstract}

Index Terms- rh-GCSF; Escherichia coli; Inclusion bodies; purification; Solubilization; Refolding

S. Abolghasemi Dehaghani is with the Dept. Biology, Science \& Research Branch, Islamic Azad University, Tehran, Iran, (corresponding author to provide phone:; fax: +98+21-88970258; e-mail: bio86.shai@yahoo.com ).

V. Babaeipour is with the Biochemical Engineering Group, Biotechnology Research Center, Tehran, Iran,(corresponding author to provide phone:; fax: +98+21-22974605; e-mail: baba1@sbmu.ac.ir).

M.R. Mofid is with the Isfahan University of medical sciences (e-mail: mohrezamofid@hotmail.com,mofid@pharm.mui.ac.ir).

A. Divsalar is with the Department of Biological Sciences, Tarbiat Moallem University, Tehran, Iran,( e-mail: divsalar@ibb.ut.ac.ir )

F. Faraji is with the Dept. Biology, Science \& Research Branch, Islamic Azad University, Tehran, Iran,( e-mail: visionbsh@gmail.com).

\section{INTRODUCTION}

Development of inexpensive and simple culture media is always favorable for commercial production of recombinant proteins in E. coli. Many of the efforts aimed at increasing recombinant protein production in bacterial strains have been directed to maximizing the biomass production with the high cell density cultivation method and little is known about the effects of media composition on the expression of recombinant proteins $[1,2]$.

Hence In this study, at first the effects of medium composition on the production of recombinant human Granulocyte-Colony Stimulating Factor (rh-GCSF) was investigated in batch culture; and then a simple and cost-effective downstream process for the economical production of rh-GCSF is developed.

The high-level expression of eukaryotic proteins in E. coli often leads to formation of insoluble inclusion bodies (IBs) in the cytoplasm or periplasm. Inclusion bodies are dense but porous particles of aggregated protein that Usually only one or a few different proteins are inside the IB, and no ribosomal components or nucleic acids are resent and they are held together by non-covalent hydrophobic or ionic bonds.

IBs have some native-like protein structures, but also have an increased amount of non-native $\beta$-sheet [3]. Three Factors that contribute to inclusion body (IB) formation:

1) Inclusion bodies form most often as a result of overexpression of a non-native protein.

2) Hydrophobic proteins form IBs more readily.

3) Non-native proteins with disulfide bonds are prone to form IBs because the disulfide bridge cannot form in the cytosol Accidental oxidation can also lead to improper disulfide formation[ 3,5$]$.

Culture conditions such as temperature, $\mathrm{pH}$, and nutrient supply play a very important role in controlling the partition of the recombinant protein into soluble and insoluble fractions. Recovery of active material from (IBs) is often difficult and involves two general steps: protein solubilization in a denaturant and protein refolding [3]. In general, proteins expressed as inclusion bodies are solubilized by the use of high concentrations of chaotropic solvents

Human G-CSF, a single chain polypeptide containing 174 
amino acid residues $(\mathrm{MW}=18,800, \mathrm{pI}=6.1)$, is one of the hemopoietic growth factors which plays an important role in stimulating proliferation, differentiation, and functional activation of blood cells. It contains a free cysteine at position 17 and two intramolecular disulfide bonds [4].

When rh-GCSF is produced by E. coli, the formation of disulfide bonds is either incorrect or inhibited because the reducing environment of bacterial cytosol, and it is accumulated in the form of IBs.

Earlier reports indicate that the levels of rh-GCSF expressed in E. coli was at moderate to high levels (10-35\%) $[7,8]$, and the yield of the final product was very poor and far from acceptable. This is probably because of unproductive downstream process technologies like isolation of protein IBs with low purity and recovery, misfolding, aggregate formation and unoptimized conditions of protein refolding, and chromatographic processes [5]. Therefore in this research has been tried to develop a well-organized and scalable process for recombinant human G-CSF from E. coli batch cultivation.

\section{MATERIALS AND Methods}

\section{A. Microorganism and vector system}

E. coli BL21 (DE3) (Novagen, Inc.) was used as the host for rh-GCSF expression. This strain was transformed with a commonly available plasmid, pET23a inducible expression vector (Novagen,Inc.), in which the rh-GCSF gene (Biotehnology Research Center, Tehran, Iran) was inserted into the NotI and NdeI sites. Host cells were transformed with the plasmid using the calcium chloride procedure. Transformed cells were spread on several LB agar plates containing $100 \mathrm{mg} / \mathrm{l}$ ampicilin.

\section{B. Media and solutions}

LB (Luria-Bertani) medium was used for plate cultivation of E. coli strain BL21 (DE3) and M9 medium was used for preparation of seed culture. M9 medium was used for preparation of seed culture. The M9 modified medium consisted of $10 \mathrm{~g}$ glucose, $15 \mathrm{~g} \mathrm{~K}_{2} \mathrm{HPO}_{4}, 7.5 \mathrm{~g} \mathrm{KH} \mathrm{KH}_{4}, 2 \mathrm{~g}$ Citric acid, $2.5 \mathrm{~g}\left(\mathrm{NH}_{4}\right) 2 \mathrm{SO}_{4}, 2 \mathrm{~g} \mathrm{MgSO}_{4} .7 \mathrm{H}_{2} \mathrm{O}$, and $1 \mathrm{ml}$ trace element solution per liter. The trace element solution contained $2.8 \mathrm{~g} \mathrm{FeSO}_{4} \cdot 7 \mathrm{H}_{2} \mathrm{O}, 2 \mathrm{~g} \mathrm{MnCl}_{2} 4 \mathrm{H}_{2} \mathrm{O}, 2.8 \mathrm{~g}$ $\mathrm{CoSO}_{4} .7 \mathrm{H}_{2} \mathrm{O}, 1.5 \mathrm{~g} \mathrm{CaCl}_{2} .2 \mathrm{H}_{2} \mathrm{O}, 0.2 \mathrm{~g} \mathrm{CuCl}_{2} .2 \mathrm{H}_{2} \mathrm{O}$, and 0.3 g $\mathrm{ZnSO}_{4} .7 \mathrm{H}_{2} \mathrm{O}$ g per liter in $1 \mathrm{M} \mathrm{HCl}$. Batch cultivations were simultaneously carried out in two 21 bench-top bioreactors with the working volume of $11[1]$.

\section{Batch Cultivation}

Batch culture was started by adding $100 \mathrm{ml}$ of an overnight-incubated seed culture $\left(\mathrm{OD}_{600}=0.7-1\right)$ into the bioreactor containing $900 \mathrm{ml}$ of medium. The $\mathrm{pH}$ was controlled at $7 \pm 0.05$ by the addition of $25 \%(\mathrm{w} / \mathrm{v}) \mathrm{NH}_{4} \mathrm{OH}$ or $3 \mathrm{M} \mathrm{H}_{3} \mathrm{PO}_{4}$. Dissolved oxygen was controlled at $30-40 \%$ of air saturation by controlling both the inlet air and agitation rate. Foaming was controlled by adding silicon-antifoaming reagent. In batch culture, cells were induced by the addition of IPTG ( $1 \mathrm{mmol} / \mathrm{l})$ when initial DCW $(2.2 \mathrm{~g} \mathrm{DCW} / 1)$ reached a considered level [6]. Then, the production phase continued until the growth ceased. All batch fermentations were performed twice.

\section{Rh-GCSF purification}

Cell lysis and $I B$ recovery: The fermented broth was centrifuged at $4{ }^{\circ} \mathrm{C}$ and $8000 \mathrm{~g}$ for $30 \mathrm{~min}$ and the obtained pellet was washed twice with $50 \mathrm{mM}$ phosphate buffer $\mathrm{pH}$ 7.4 .

The wet cells $(50 \mathrm{~g})$ were suspended in $200 \mathrm{ml}$ of lysis buffer. The lysis buffer composition was $50 \mathrm{mM}$ Tris- $\mathrm{HCl}$ containing $1 \mathrm{mM}$ EDTA, $1 \mathrm{mM}$ PMSF. The cells were broken by passing the medium through a homogenizer three times (NIRO-SOAVI) at 800 bar. The cells were cooled to $4^{\circ} \mathrm{C}$ between each pass. The cell homogenate was centrifuged for $30 \mathrm{~min}$ at $6000 \mathrm{~g}$ at $4^{\circ} \mathrm{C}$, the supernatant was discarded and the inclusion bodies recovered.

IBs washing: The IBs pellet obtained in previous step was resuspended in wash buffer and incubated $40 \mathrm{~min}$ and recovered by centrifugation at $25-28^{\circ} \mathrm{C}$ for $30 \mathrm{~min}$ at $8000 \mathrm{~g}$. The washing protocol is $2.5 \mathrm{~g} \mathrm{l-1}$ Triton X-100 in $50 \mathrm{mM}$ Tris- $\mathrm{HCl} \mathrm{pH} 8.0$ containing 5mM EDTA and $1 \mathrm{mM}$ PMSF. In the second washing, the IBs pellet was resuspended in wash buffer and incubated $40 \mathrm{~min}$ and recovered by centrifugation at $25-28^{\circ} \mathrm{C}$ for $30 \mathrm{~min}$ at $8000 \mathrm{~g}$. The washing protocol is $1 \mathrm{M}$ urea.

IB solubilization and refolding: Washed inclusion bodies were dissolved in $30 \mathrm{~m}$ M Tris- $\mathrm{HCl}, \mathrm{pH}=8$, containing $6 \mathrm{M}$ urea, $1 \mathrm{mM}$ EDTA and $100 \mathrm{mM}$ GSH, The solution was incubated at $25-28^{\circ} \mathrm{C}$ for $45 \mathrm{~min}$ and spun down at $10,000 \mathrm{~g}$ for $30 \mathrm{~min}$ to get rid of insoluble cell debris and recovered by centrifugation at $25-28{ }^{\circ} \mathrm{C}$ for $30 \mathrm{~min}$ at $8000 \mathrm{~g}$. and then solubilized inclusion bodies was refolded by refolding buffer that the refolding buffer protocol is $30 \mathrm{mM}$ Tris- $\mathrm{HCl}(\mathrm{pH}$ =7.5), $2 \mathrm{mM}$ GSSG, $20 \mathrm{mM}$ GSH, $1 \mathrm{mM}$ EDTA, 3M Urea and incubated 12 hours at $4{ }^{\circ} \mathrm{C}$. After completion of refolding, the protein $\mathrm{pH}$ was adjusted with $2 \mathrm{M}$ citric acid and centrifuged at $10,000 \mathrm{~g}$ for $20 \mathrm{~min}$ at $4^{\circ} \mathrm{C}$.

Anion Exchange Chromatography: The $\mathrm{pH}$ of Refolded protein was adjusted to 5-6 by adding $2 \mathrm{M}$ Acetic acid and then loaded in mono Q column in FPLC (SYKAM-S2100). The column temperature and flow rate were maintained at $20{ }^{\circ} \mathrm{C}$ and $1 \mathrm{ml} / \mathrm{min}$ respectively throughout the process. The column was equilibrated with 3 bed vol. of $25 \mathrm{mM}$ sodium acetate buffer $(\mathrm{pH}=4.5)$. The refolded protein sample was directly loaded on to the column at the same flow rate. The column was extensively washed with 3 beds vol. of the same buffer but with $1 \mathrm{M} \mathrm{NaCl}$.

\section{E. SDS-PAGE}

In the reduced SDS-PAGE 15\% gel and three standards of rh-GCSF (Neupogen ${ }^{\circledR}$, Roche, Germany), (PDgrastim, Pooyesh Darou, Iran) and a molecular weight marker (\#SM0431, Fermentas) were used. Sample buffer [0.5 M Tris $\mathrm{pH}$ 6.8, 50\% (v/v) glycerol, 100 g 1-1 SDS, 20 g 1-1 bromophenol blue and $50 \mathrm{~g} \mathrm{l-1}$ 2-mercapto ethanol (2-ME) was added to three samples and standards before boiling for 5 min. The samples were loaded on to the gel and ran at a constant voltage of $120 \mathrm{~V}$ for $100 \mathrm{~min}$. Gels were stained with Coomassie brilliant blue R250 [10]. 


\section{F. Western blotting}

For confirmation of rh-GCSF band in gel, western blotting with polyclonal human GCSF antibody was performed. Separated proteins on the SDS-PAGE gels were transferred into a poly-vinylidene fluoride (PVDF) membrane (Roche Diagnostic, Germany) for recognizing the exact existence of rh-GCSF. PVDF sheet was blocked with $3 \%$ BSA in TBS-T solution (20 mM Tris-HCl, pH 7.5, $150 \mathrm{~mm} \mathrm{NaCl}$, and $0.05 \%$ Tween 20). Then, anti-GCSF polyclonal antibody was added at a dilution of 1:500 in TBS-T solution for $1 \mathrm{~h}$. A second incubation with HRP anti-rabbit $(1: 1000)$ in TBS-T was carried out and the third incubation of 5-10 min was done with Diaminobenzine (DAB) solution. $(0.5 \mathrm{mg} / \mathrm{ml} \mathrm{DAB}$, $0.1 \% \mathrm{H} 2 \mathrm{O} 2)$ [11].

\section{RESULTS AND DisCUSSION}

\section{A. Purification of human G-CSF}

\section{- Cell lysis and IB isolation}

The rh-GCSF IBs in the cytoplasm of E. coli were isolated by lysing the bacterial cells. The efficiency of cell lysis was experiential at different sonication pulses of 5, 10, 15 and 20 $\mathrm{s}$ and at a different homogenizer pressure $(600,800.1200$ bar $)$ and at different times.

The highest IB recovery was observed by passing the medium through a homogenizer three times at $800 \mathrm{bar}$, and it is better to use homogenizer in industrial process. Cell lysis was measured by plating the lysate suspension on LB-agar followed by colony counting.

IB recovery was measured by the Bradford method. This condition was chosen as the optimum for further work. Thus optimization of the early stages of the downstream process will have an impact on the overall process yield and final product purity.

- IB washing

The IBs separated after homogenizer was found to be contaminated with endotoxins, host DNA and HCPs. These

Fig.1

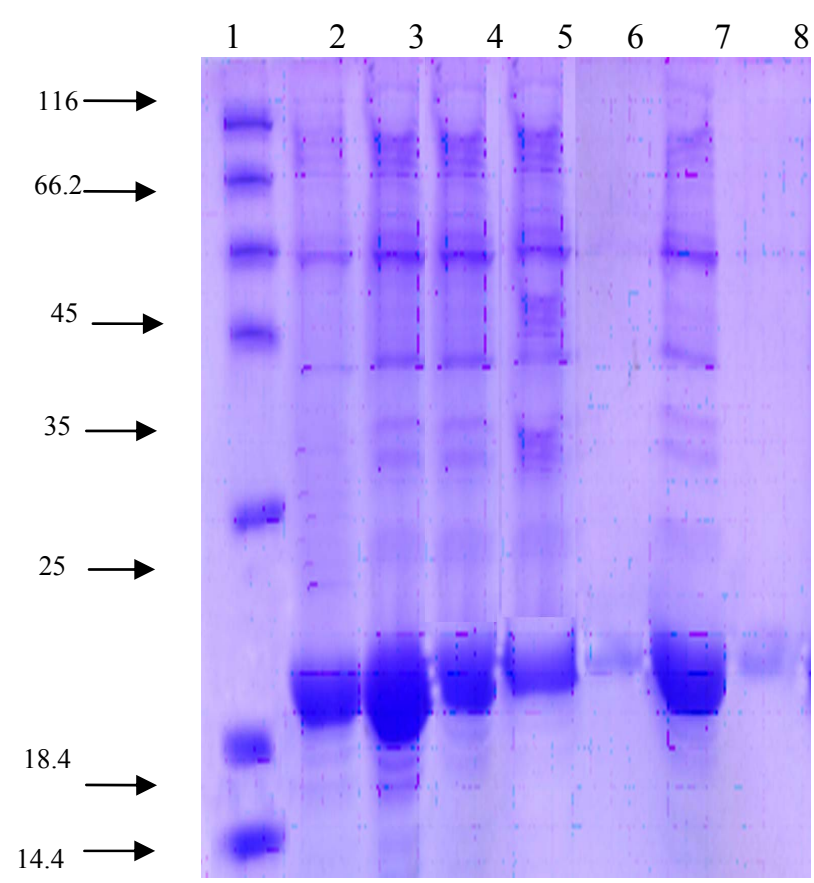

Fig.1: SDS-PAGE (15\%) Use different concentration of urea in IB solubilization . Lane-1: Molecular weight marker (\#SM0431, Fermentas), lane-2: rh-GCSF in water and add loading buffer,lane -3: rh-GCSF in $8 \mathrm{M}$ Urea - $\mathrm{pH}$ 12, lane- 4: - rh-GCSF in $3 \mathrm{M}$ Urea - $\mathrm{pH}$ 12, lane-5: rh-GCSF in 8 M Urea - pH 8 ,lane-6: rh-GCSF in 8 M Urea - pH 6,lane-7: rh-GCSF pellet in $8 \mathrm{M}$ Urea - $\mathrm{pH}$ 6,lane-8: rh-GCSF in $8 \mathrm{M}$ Urea - $\mathrm{pH} 8$ - 0.1 M Cystein.

Impurities interfere with refolding and significantly affect the process yield and purity.

Two-step wash procedure eliminates endotoxins, proteins and DNA of the host cell. Removal of these impurities and obtaining the IBs with high recovery and purity was demanding. Therefore optimization of detergent concentration has effect on the efficiency of IB recovery.

We use different concentration of different detergents; finally we found that Triton X-100 was used to solubilize the bacterial cell wall components that infect the inclusion body preparation. Also, sodium deoxycholate to remove any residual cell debris particles, especially lipopolysaccharides units that contribute to the unacceptable levels of endotoxins in protein preparations from $E$. coli and urea are better than others.

- IB solubilization and refolding

Key to the development of an efficient and cost-effective denaturant-based solubilization step is the determination of the minimum amount of denaturant needed to solubilize the protein and to allow for full bioactivity recovery in the refolding step.

Because a method has been described for G-CSF extraction from IBs produced in E. coli used high amount of detergent and chaotropic agent, and hence additional steps

Fig.2

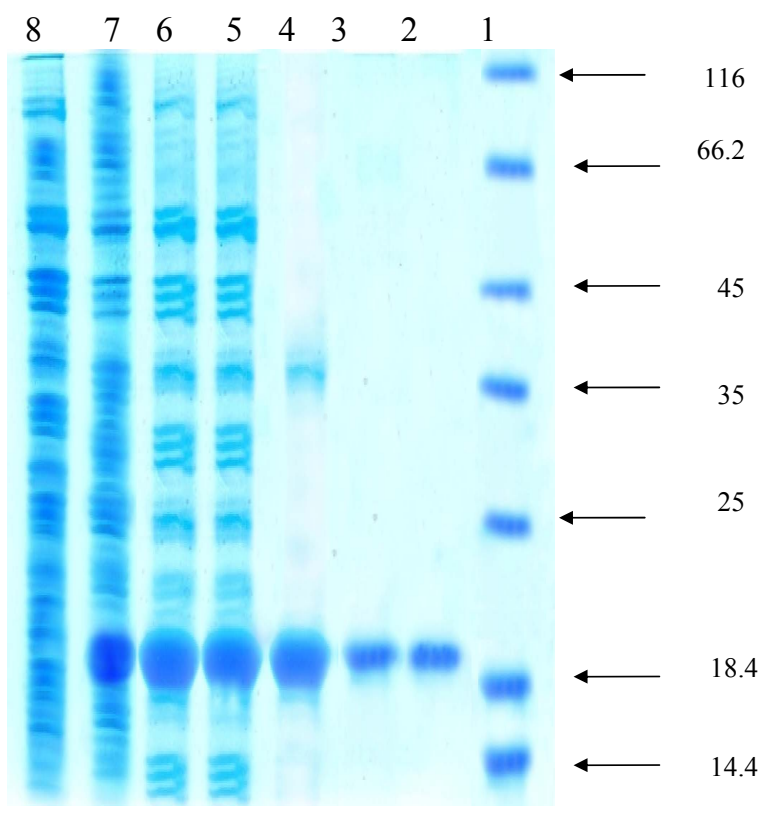

Fig.2: The purity of the rh-GCSF at different process stages was observed by SDS-PAGE gel. Lane-1: molecular weight marker(\#SM0431, Fermentas), lane-2: reference standard (Neupogen () , lane-3: purified rh-GCSF, lane-4: : refolded rh-GCSF, lane-5: rh-GCSF protein inclusion body pellet, lane-6: rh-GCSF after two-step wash, lane-7: fermented broth (before harvesting), lane-8: fermentation sample (before induction) 


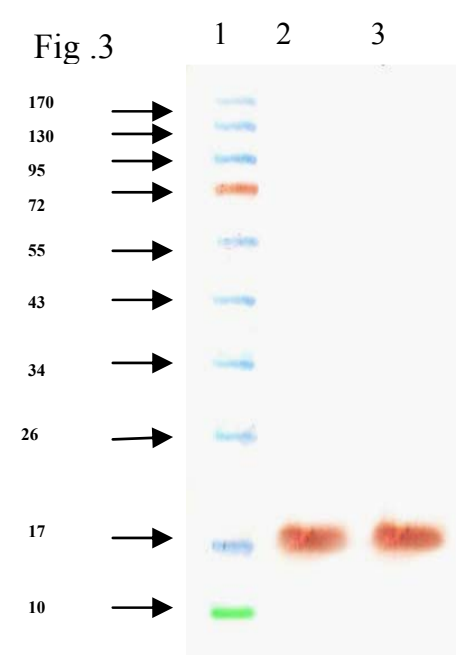

Fig3: Western blot of purified rh-GCSF showing a single protein bond .Lane-1: molecular weight marker(\#SM0671, Fermentas), lane-2: purified rh-GCSF, lane-3: reference standard (Neupogen $\left.{ }^{\circledR}\right)$.

had to be in use to eliminate these agents, so we optimize the amount of denaturant use in solubilization.

Since rh-GCSF is hydrophobic in nature and conductivity sensitive, the combination of denaturant/reducing agent has an impact on solubilization and refolding. Hence we use different concentration of urea $(3,6,8 \mathrm{M})$ in different $\mathrm{pH}(6$, 8, 12) (Fig1).

The key to refolding is to remove enough denaturant to allow the protein to fold properly, but keep enough denaturant in the refolding buffer to allow proteins to fold/refold several times until attains the proper conformation protein.

- Anion Exchange Chromatography

The ion-exchange column is primarily useful for the removal of endotoxins, nucleic acids, HCPs and product-related impurities.

In this study we use FPLC (SYKAM-S2100) with mono Q Column. The results obtained determine improvement of the method for effective removal of impurities and high recovery of protein with a monomer peak purity of $>98 \%$. In the present study we envisage a simple, fast, reliable and reproducible process for higher yields and a quality product with high purity.

The SDS-PAGE gel electrophoresis shows that the purity of the purified rh-GCSF by $I E C$ is over than $99 \%$. The final step of the purification showed a single band of $18.8 \mathrm{kDa}$, similar to reference standard. The same general pattern was revealed when the sample shown in Figure 3 was transferred from SDS-PAGE to a nitrocellulose membrane and immunodetected with G-CSF specific antiserum, confirming a typical profile (Fig2, Fig.3).

\section{CONCLUSION}

In the present study, we developed an efficient and scalable procedure for production and purification of recombinant human (rh-GCSF) of E. coli. By the using of the new developed method, $2.2 \mathrm{~g} \mathrm{l}^{-1}$ rh-GCSF was produced in batch cultivation with recovery yield about $40 \%$ and with purity over than $99 \%$. The process established in this study may be functional in the recovery of other proteins expressed in $E$. coli as cytoplasmic IBs.

\section{REFERENCES}

[1] V. Babaeipour, S. A. Shojaosadati, R. Khalilzadeh, N. Maghsoudi, A.M. Farnoud, " Enhancement of Human $\gamma$-Interferon Production in Recombinant E. coli Using Batch Cultivation(Periodical style-Accepted for publication) ," Applied Biochemistry and Biotechnology, 2009, to be published

[2] S.A. Shojaosadati, S. M. Varedi K, V. Babaeipour, A. M.Farnoud, "Increasing Protein Production in High Cell Density Cultures", 2008, Iranian journal of Biotechnology.

[3] M.M. Carrio', A. Villaverde . "Construction and deconstruction of bacterial inclusion bodies", Journal of Biotechnology. 2002,96 3-12.

[4] C. Z. Wang, J. F. Liu, X. D. Geng . " Refolding with Simultaneous Purification of Recombinant Human(GCSF) from E. coli Using Strong Anion Exchange Chromatography", Chinese Chemical Letters. 2005, Vol. 16, No. 3, pp 389-392.

[5] V. K. R. Dasari, D. Are, V. R. Joginapally,L. N. Mangamoori, K. S. B. R. Adibhatla " Optimization of the downstream process for high recovery of rh-GCSF from inclusion bodies expressed in Escherichia coli ", Process Biochemistry. 2008, 43-566-575.

[6] B.S. Kim, S.C.Lee, S.Y. Lee, Y.K.Chang, H.N. Chang “ High cell density fed-batch cultivation of $E$ coli using exponential feeding combined with pH-stat" , Bioprocess Biosyst Eng .2004,26: : 147-150.

[7] R.S.Donovan, C.W.Robinson, B.R.Glick, “ Optimizing inducer and culture conditions for expression of foreign proteins under the control of the Lac promoter(Review) ,'. J. Ind. Microbiol.1996, 16: 145-154.

[8] K.Weber, J.R. Pringle, M. Osborn, “ Measurment of molecular weights by electrophoresis on SDS acrylamide gel," Enzymology, vol.26, 1972, PP. 3-27.

[9] W.N. Burnette, "Western Blotting": Electrophoretic transfer of proteins from sodium dodecyl sulfatepoly acrylamide gels to unmodified 